\title{
Can Equity Volatility Explain the Global Loan Pricing Puzzle?*
}

\author{
Lewis Gaul ${ }^{\dagger} \quad$ Pinar Uysal ${ }^{\ddagger}$
}

September 30, 2011

\begin{abstract}
We examine whether equity volatility can explain the difference in syndicated corporate loan spreads paid by U.S. and European borrowers first documented by Carey and Nini (2007). We argue that OLS estimates of the association between equity volatility and loan spreads are biased and inconsistent. We suggest instrumental variables that potentially identify consistent estimates. Our instrumental variable results indicate that there is no statistically significant difference in loan spreads paid by U.S. and European borrowers, and that OLS estimates of the association between idiosyncratic equity volatility and corporate loan spreads are biased downward by about a factor of 5.
\end{abstract}

JEL codes: E40, G12, G15, G21

In this paper we examine whether equity volatility can explain the difference in syndicated corporate loan spreads between the U.S. and Europe documented by previous research. Carey and Nini (2007) provide evidence that interest rates spreads in Europe are 30 basis points

${ }^{*}$ The views expressed in this paper are those of the authors alone and do not necessarily reflect those of the Office of the Comptroller of the Currency or the U.S. Department of the Treasury.

${ }^{\dagger}$ Financial Economist, Policy Analysis Division, Office of the Comptroller of the Currency, 250 E St. SW, 3rd Floor, Washington, DC 20219, e-mail: Lewis.Gaul@occ.treas.gov

†Post-doctoral Fellow, École Polytechnique Fédérale de Lausanne (EPFL), Chair of International Finance, Station 5, Office ODY 2.17, CH - 1015 Lausanne, Switzerland, e-mail: pinar.uysal@epfl.ch 
lower than in the United States, and Houston, Itzkowitz, and Naranjo (2007) present evidence that loan spreads are 40 basis points lower in Europe compared to the U.S. These authors' results suggest that there must be a barrier that prohibits U.S. borrowers from accessing the lower cost European loan market. This is puzzling because several large lenders extend credit to both markets, and many large borrowers have global operations in both continents. Intuition suggests that many of these firms could easily access either market.

While these studies control for numerous control variables from the literature that examines the determinants of cost of corporate loan and bond financing, they do not directly control for firm volatility. It is well established in the finance and economics literature that firm volatility is a primary determinant of the cost of corporate debt financing and that equity volatility is a proxy for firm volatility. Beginning with Merton (1974), contingent claims models of corporate debt valuation predict that cost of debt financing is a function of firm's total debt, asset value, and asset value volatility. These models also predict that equity volatility is a direct function of firm's asset volatility, which motivates the use of equity volatility as a proxy for firm's asset volatility. Empirical evidence confirms the predictions of these models. Campbell and Taksler (2003) present evidence equity volatility has substantial explanatory for corporate bond yields, and that idiosyncratic volatility can explain as much cross section variation in bond yields as credit ratings. In addition, Santos (2011) and Santos and Winton (2010) find that equity volatility to have significant explanatory power for syndicated loan spreads in the U.S. market.

Although equity volatility has been shown to have significant explanatory power for loan spreads, we cannot expect it to explain the difference in U.S. and European loan spreads unless there is a large difference in average equity volatility between U.S. and European firms. Recent research suggests that there is. Bartram, Brown, and Stulz (2009) present 
evidence idiosyncratic equity volatility is larger in the U.S. compared to other countries, however they find mixed evidence regarding the relative magnitudes of systematic equity volatility. They suggest that idiosyncratic volatility is greater in countries with greater government stability and quality, and financial development, and that greater idiosyncratic equity volatility reflects greater risk taking rather than informed trading. In Figures (1) and

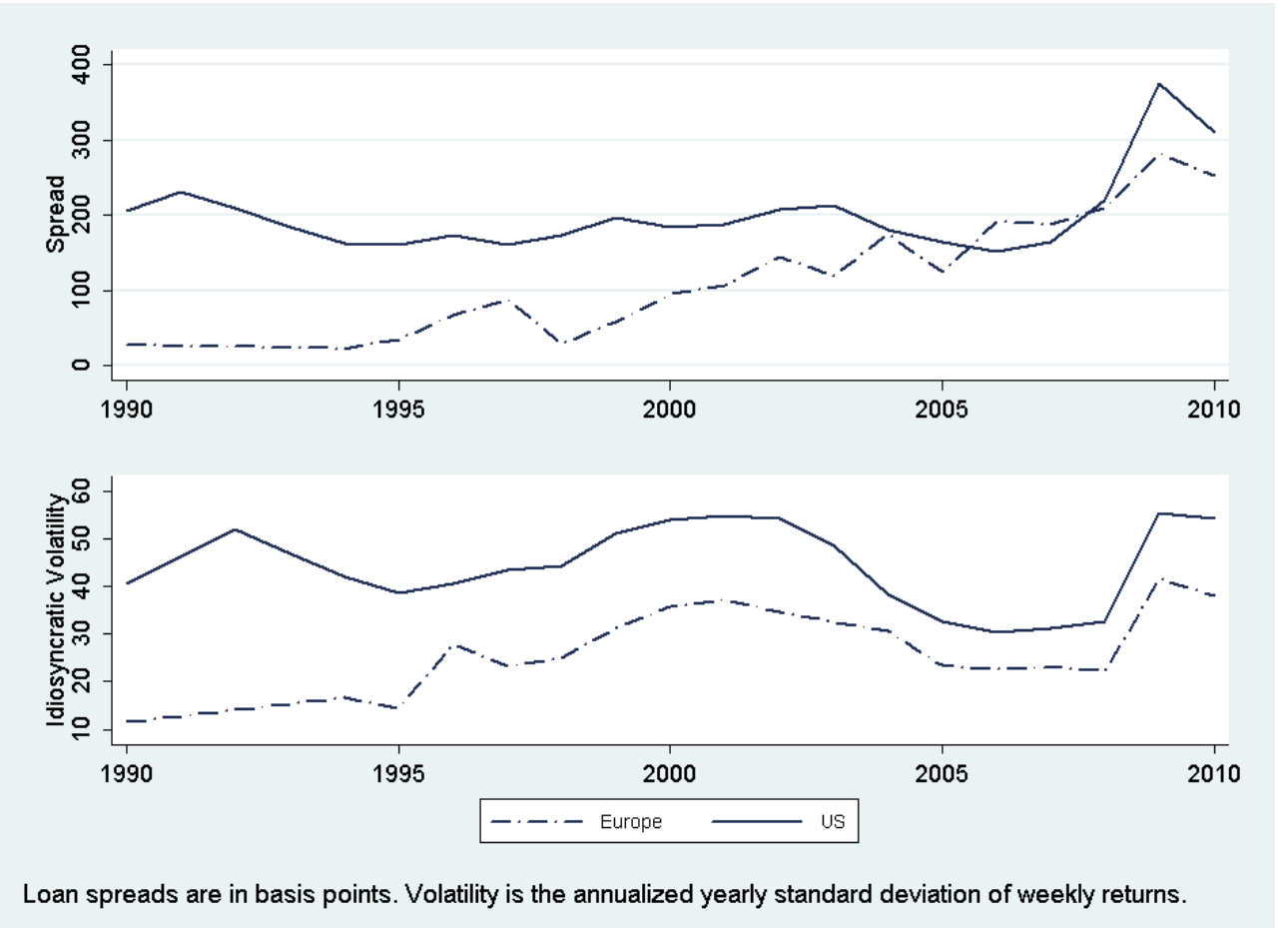

Figure 1: All-In-Drawn Spread and Idiosyncratic Volatility

(2), we plot average loan spreads along with estimates of borrower's average idiosyncratic and systematic equity volatility for U.S. and European borrowers in the Dealscan database over the years 1990-2010. Figure (1) shows that U.S. firms have greater average idiosyncratic volatility as compared to European firms for most of the data sample and that gap has narrowed over time. In addition, average idiosyncratic volatility appears to follow a similar cyclical pattern for both U.S. and European firms. This is consistent with the analysis of 
Bekaert, Hodrick, and Zhang (2012) who find that average idiosyncratic volatility is highly correlated across countries. In addition, the difference in average idiosyncratic volatility is mimicked by greater average loan spreads in the U.S. as compared to Europe. Also the gap in loan spreads narrows toward the end of the data sample. Furthermore, loan spreads for both sets of borrowers appear to follow patterns similar to idiosyncratic equity volatility. In Figure (2) the plots indicate that there is no significant pattern in the difference in average systematic volatility between U.S. and European firms. Average systematic volatility appears to follow similar trends in both the U.S. and Europe. Our graphs are consistent with the results of Bartram et al. (2009), and provide support for the claim that differences in idiosyncratic volatility between U.S. and European borrowers could potentially explain loan pricing puzzle.

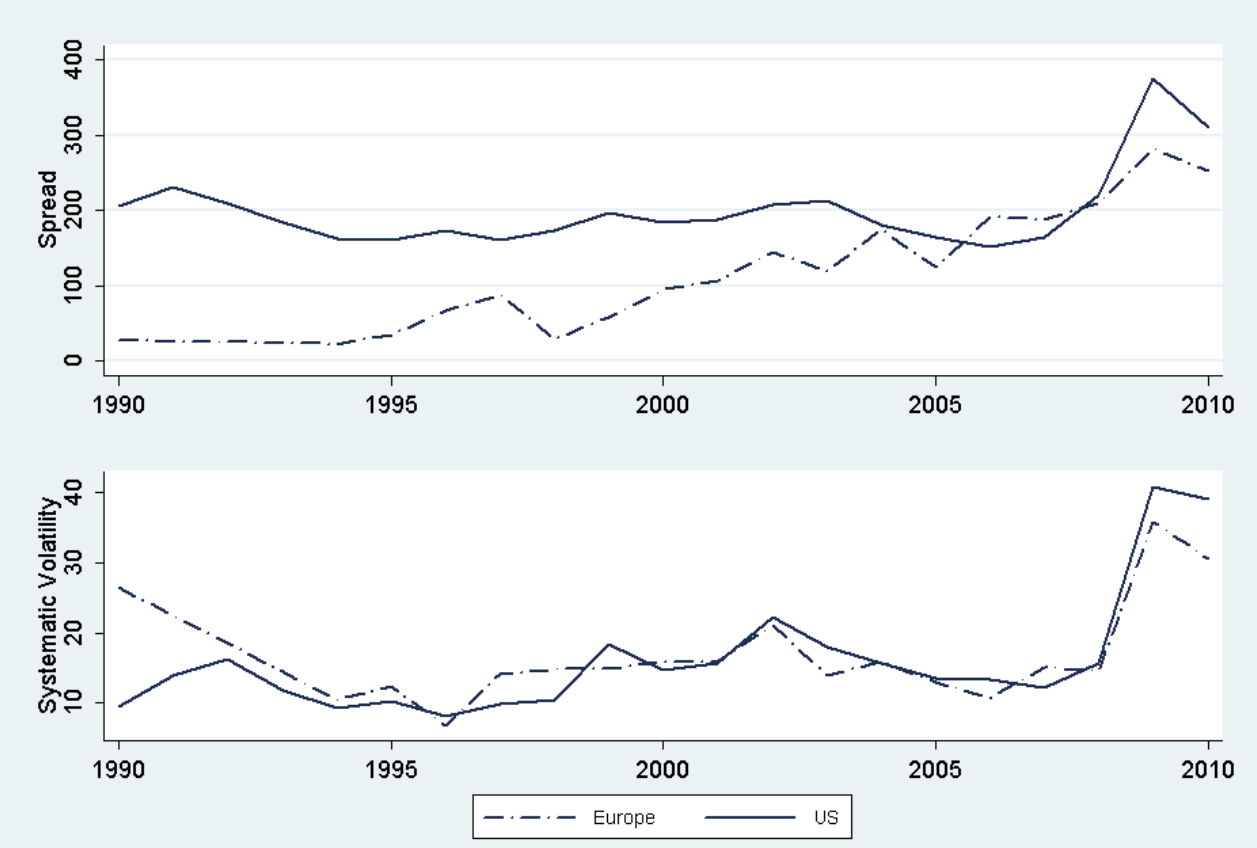

Loan spreads are in basis points. Volatility is the annualized yearly standard deviation of weekly returns.

Figure 2: All-In-Drawn Spread and Systematic Volatility 
We use a large sample of corporate loans to examine whether equity volatility, decomposed into its idiosyncratic and systematic components, can explain the loan spread differential paid by U.S. and European borrowers. We decompose borrowers' total stock return volatility into its idiosyncratic and systematic components because our preliminary analysis in Figures (1) and (2) suggests that differences in equity volatility between European and U.S. firms' are largely due to differences in idiosyncratic volatility. In addition, previous studies that examine the association between equity volatility and the cost of corporate debt financing typically follow a similar approach, or focus solely on idiosyncratic equity volatility (See Campbell and Taksler (2003), Santos (2011), and Santos and Winton (2010)). However, because equity volatility is a proxy for firm volatility, we expect that OLS estimates of the determinants of loan spread will be biased and inconsistent. Consequently, we attempt to obtain consistent estimates using an instrumental variable generalized methods of moments (IV) estimator where we instrument equity volatility with the volatility of quarterly financial statement ratios and quarterly total assets. We also control for a broad set of explanatory variables that are standard in the literature.

In our OLS models that control for idiosyncratic and systematic volatility, we estimate that loan spreads received by European borrowers are 29 basis points lower than those received by U.S. borrowers. This evidence is consistent with those of Carey and Nini (2007) and Houston et al. (2007). However our main IV results indicate that there is no statistically significant difference in loan spreads received by European and U.S. borrowers. In addition, compared to our OLS results, our IV results suggest that OLS estimates of the association between idiosyncratic equity volatility and corporate loan spreads are biased downward by about a factor of five to six. We find significant differences in coefficient estimates between our OLS and IV results. In particular, proxies for firm size are significant in our OLS models, 
but not in our IV models. Firm's credit ratings have substantial explanatory power for loan spreads in our OLS models, but little or no explanatory power in our IV models. Finally, the sign of the coefficient on firm's cash holdings switches from positive in OLS specifications to negative in IV models.

Our focus on borrower location differs from previous research by Carey and Nini (2007) and Houston et al. (2007) which mainly focus on the difference in loan spreads between loans originated in U.S. and European markets. ${ }^{1}$ We focus on borrower location because we expect that firm volatility depends on firms' domicile, rather than the market where firms' originate their loans. However a priori we expect that borrower location is highly correlated with market of syndication because borrowers overwhelmingly originate loans in their home region. And, therefore, we do not expect our results to depend on whether we use market of syndication instead of location. ${ }^{2}$ Table I, which tabulates borrowers' location against their loans' market of syndication, provides support for this claim. The tabulations indicate that with few exceptions borrowers originate loans in their home market. Carey and Nini (2007) and Houston et al. (2007) provide additional support for this claim by providing similar evidence that borrowers tend to issue loans in their home market.

\section{[ PLACE TABLE I HERE ]}

Our results have two main implications. First, our results suggest that there is no ma-

\footnotetext{
${ }^{1}$ In the syndicated loan market, there are distinct markets that operate in different regions of the globe. Markets can be thought of as a location where borrowers and lenders meet to arrange loan deals. Typically borrowers and lenders are free to choose and arrange deals in markets located outside their home domicile. In our sample, the markets that the borrowers originate loans include Africa, Asia Pacific, Eastern Europe/Russia, and Latin America/Caribbean. The market of syndication is unknown for a negligible number of loans.

${ }^{2}$ We have reproduced the analysis in this paper focusing on market of syndication rather than borrower location, and we have done so with data samples that both do and do not include firms that are located outside the U.S. and Europe. The interpretation of results are identical to those presented here and the results are available upon request.
} 
terial loan pricing difference between loans received by U.S. and European borrowers. This suggests there may not be any meaningful barriers restricting borrowers in one continent from receiving loans in the other. And, that borrowers' observed tendency to originate loans in their home domicile may be because there are not significant benefits to accessing foreign markets.

Second, our result indicate that identifying consistent estimates of the coefficients of important control variables such as equity volatility can substantially alter inferences in empirical analysis of the determinants of syndicated loan interest rates. For example, several studies control for firm size under the assumption that size is associated with fewer credit risk and asymmetric information problems. However, our proxy for firm size is no longer significant in our IV models. Also, standard risk proxies for such as credit ratings do not have significant explanatory power in our IV models. This is consistent with Campbell and Taksler (2003)'s results that idiosyncratic volatility can explain as much variation in bond yields as bond ratings. In addition, the coefficient on proxies for borrowers' cash holdings is positive in OLS estimations but negative in instrumental variable estimations. The positive sign in the OLS models is inconsistent with the notion that firms with greater cash holdings have lower risk because they have more balance sheet liquidity. In contrast, our IV results have the expected sign. In each of these cases, the control variables have strong correlations with idiosyncratic equity volatility.

The remainder of the paper is as follows. Section I presents the econometric procedure. Section II describes the data and the creation of the proxy variables. Section III shows the estimation results and robustness checks. Section IV concludes. 


\section{Empirical Model}

In this section we present our empirical model that we use to examine the determinants of loan spreads for U.S. and European borrowers. Our model is motivated by the literature that examines the determinants of syndicated loan spreads and contingent claims models of debt valuation. We model interest rate charged on corporate loans as a function of the volatility of the market value of the firm's assets, the ratio of the book value of firm's debt to the market value of firm's assets, and a set of additional control variables. We follow the approach of Carey and Nini (2007) and Houston et al. (2007) and allow loan spreads to depend on whether a borrower is located in Europe or the U.S. The model is given by the following equation:

$$
r_{i}-r_{f}=\alpha_{0}+\alpha_{1} \sigma_{A i}+\alpha_{2} \frac{D_{i}}{A_{i}}+\alpha_{3} E_{i}+\boldsymbol{\Gamma}_{\mathbf{1}}{ }^{\prime} \mathbf{Z}_{\mathbf{i}}+\varepsilon_{1 i}
$$

In Equation (1) $r_{i}-r_{f}$, is the interest rate spread on the loan, defined as the interest rate on the loan, $r_{i}$, minus the risk free rate, $r_{f}$. The risk spread depends of the volatility of the firm's assets, $\sigma_{A i}$, and borrower's leverage, $\frac{D_{i}}{A_{i}}$, which is total debt, D, divided by the market value of assets, A. $E_{i}$ is a dummy variable indicating whether the firm is located in Europe, $\mathbf{Z}$ is the vector of additional control variables, and $\varepsilon_{1 i}$ is the residual.

Because firm's asset volatility is unobservable, the parameters of the loan spread equation cannot be identified. One approach is not to account for firm volatility, and leave it as an omitted variable. However, since volatility is likely correlated with other control variables, this might result in biased and inconsistent coefficient estimates. A typical approach used by the literature is to use firm's equity volatility as a proxy for firm's asset volatility. Studies that similarly use equity volatility as a proxy for firm volatility include Gilchrist, Sim, and 
Zakrajšsek (2010), Santos (2011), Santos and Winton (2010), and Shumway (2001). We interpret this approach as implying that equity volatility can be written as a function of firm's asset volatility and market leverage:

$$
\sigma_{E i}=\beta_{0}+\beta_{1} \sigma_{A i}+\beta_{2} \frac{D_{i}}{A_{i}}+\varepsilon_{2 i}
$$

In equation (2) the error term $\varepsilon_{2 i}$ is the difference between our estimate of idiosyncratic equity volatility and the lenders' assessment of firm volatility. We interpret the error term in multiple ways. First, if lenders use estimates of idiosyncratic or systematic equity volatility as a proxy for borrower volatility then the error term could simply reflect the difference between our estimates and lenders'. For instance, lenders could use daily returns, while we use weekly returns in our analysis. Or, if lenders use different asset pricing models to estimate idiosyncratic and systematic equity volatility, the error term could reflect these differences. Second, lenders could implement a variety of non-linear models to estimate borrowers' asset volatility from estimates of equity volatility. ${ }^{3}$ And, the error term could reflect differences between these assessments and our estimates of equity volatility. Third, if the lenders use other proxies for firm volatility such as cash flow or sales volatility, the error could reflect differences between these proxies and our estimates of equity volatility.

One can argue that equity volatility could also be a function of other control variables. In particular equity volatility could be a function of whether a firm is located in U.S. or Europe, independent of firm's asset volatility and leverage. However our key identifying assumption is that the difference in firm equity volatility between U.S and European firms are accounted for by differences in firms' asset volatility and firms' leverage. Bartram et al. (2009) present

\footnotetext{
${ }^{3}$ These models are usually derived from structural models of corporate debt valuation. For an example of these type of models see McNeil et al. (2005), Lando (2004), and Cairns (2004).
} 
evidence that supports this claim. Their results indicate that the difference in idiosyncratic equity volatility between U.S. and foreign firms is likely due to greater risk taking by U.S. firms. We discuss the importance of this identifying assumption below.

In the next step, we solve for asset volatility in equation (2) as:

$$
\sigma_{A i}=\frac{\sigma_{E i}}{\beta_{1}}-\frac{\beta_{0}}{\beta_{1}}-\frac{\beta_{2}}{\beta_{1}} \frac{D_{i}}{A_{i}}-\frac{\varepsilon_{2 i}}{\beta_{1}}
$$

and insert it into equation (1). We assume that the error terms $\varepsilon_{1 i}$ in equation (1) and $\varepsilon_{2 i}$ in equation (2) are independent and are orthogonal to the explanatory variables. This results in the following regression model:

$$
\begin{aligned}
r_{i}-r_{f} & =\left(\alpha_{0}-\frac{\alpha_{1} \beta_{0}}{\beta_{1}}\right)+\frac{\alpha_{1}}{\beta_{1}} \sigma_{E i}+\left(\alpha_{2}-\frac{\alpha_{1} \beta_{2}}{\beta_{1}}\right) \frac{D_{i}}{A_{i}}+\alpha_{3} E_{i}+\boldsymbol{\Gamma}_{\mathbf{1}}{ }^{\prime} \mathbf{Z}_{\mathbf{i}}+\left(\varepsilon_{1 i}-\frac{\alpha_{1}}{\beta_{1}} \varepsilon_{2 i}\right) \\
& =\rho_{0}+\rho_{1} \sigma_{E i}+\rho_{2} \frac{D_{i}}{A_{i}}+\alpha_{3} E_{i}+\boldsymbol{\Gamma}_{\mathbf{1}}{ }^{\prime} \mathbf{Z}_{\mathbf{i}}+\eta_{i}
\end{aligned}
$$

In contrast to equation (1), equation (4) models interest rate spreads as a function of equity volatility rather than asset volatility. Models of this type are unable to identify the parameters $\alpha_{0}, \alpha_{1}$, and $\alpha_{2}$. If our previously mentioned assumption that European dummy variable or the control variables in the $\mathbf{Z}$ matrix do not have an independent association with equity volatility in equation (2) is valid, then we are able to identify $\alpha_{3}$ and $\boldsymbol{\Gamma}_{\mathbf{1}}$.

If we try to estimate the coefficients in equation (4) with OLS, then we would likely get biased and inconsistent coefficient estimates, since equity volatility is correlated with the error term, $\eta_{i}$. This is because

$$
\operatorname{COV}\left(\sigma_{E i}, \varepsilon_{2 i}\right)=\operatorname{VAR}\left(\varepsilon_{2 i}\right) \neq 0 \Rightarrow \operatorname{COV}\left(\sigma_{E i}, \eta_{i}\right)=-\rho_{1} V A R\left(\varepsilon_{2 i}\right) .
$$


The relationship between the equity volatility and the error term will lead to a downward biased estimate of $\rho_{1}$, even if all other control variables are exogenous. Consistent estimates could be obtained by finding an instrumental variable correlated with equity volatility, but orthogonal to $\eta_{i}$. One solution is to use another variable that could be a proxy for for $\sigma_{A i}$, but is uncorrelated with $\eta_{i}$.

We use proxies for the volatility of quarterly financial statement ratios and balance sheet variables as instruments for equity volatility. Our instruments include standard deviation of total assets, the standard deviation of the ratio of total equity to total assets, and the standard deviation of cash and short term investments to assets. Our reasoning is simple. We suggest that if there is greater variation in these three variables derived from borrowers' quarterly financial statements, then investors' valuation of firms' assets should change more frequently. Hence, firms with more volatile financial statements should have more volatile asset values, and as a result, more volatile stock returns. We use these variables as instruments for both idiosyncratic and systematic equity volatility. We relate our instrumental variables to firms' asset volatility and leverage with the following equation.

$$
\sigma_{\mathbf{B i}}=\delta_{0}+\delta_{1} \sigma_{A i}+\delta_{2} \frac{D_{i}}{A_{i}}+\varepsilon_{3 i}
$$

As already mentioned, in order for our instruments to identify the consistent estimates of the coefficients in equation (4), the instruments should not be correlated with the error terms $\varepsilon_{2 i}$ and $\varepsilon_{1 i}$. As previously mentioned, we interpret $\varepsilon_{2 i}$ as the difference between our estimate of equity volatility and lenders' assessment of firm volatility. We do not suspect that there are convincing reasons why our instruments would be correlated with $\varepsilon_{2 i}$. If our instruments are orthogonal to $\varepsilon_{1 i}$, this would imply that our instruments are not omitted variables. However, we recognize one could argue that lenders, like equity investors, could base their assessment 
of firm volatility directly on estimates of the volatility of balance sheet variables. And, this would imply that measures of the volatility of balance sheet variables should be included in the regressions as explanatory variables for loan spreads, rather than as instruments of equity volatility. To the extent that stock prices reflect publicly available information we expect estimates of equity volatility should subsume the information in our instrumental variables.

\section{Data Sample and Summary Statistics}

We gather data from several sources. We obtain information on corporate loan contracts from the Loan Pricing Corporation's Dealscan database, data on U.S. firms' financial statements from Compustat, data from European and non-U.S. firms' financial statements from Compustat Global, data on U.S. firms stock prices from CRSP, and data on European firms stock prices from the Compustat Global Security Daily database. We also acquire data on exchange rates and interest rates from the Federal Reserve Bank of St. Louis web site.

We begin with with the Dealscan database and gather data on individual corporate loans originated by borrowers located in the United States and Europe. Each observation is an individual corporate loan facility and consists primarily of syndicated loans; however, there are a small amount of loans made by an individual lender to a borrower. For an overview of the syndicated loan market and the Dealscan database, see Strahan (1999). Our data loan sample spans the years 1987 through 2010. The Dealscan database has information on a small number of loans in the late 1980's and the number of loans in the database begins to increase in the mid 1990's. There is substantial coverage of the U.S. market throughout the time frame while coverage of the European market largely concentrated in late 1990's 
and afterwards. We merge Dealscan with Compustat and Compustat Global data for firms' fiscal years that end one year prior to the calendar year in which a loan is originated. We merge Dealscan with Compustat data from 1986 to 2009 and Compustat Global data for the years 1989 through 2009. The time frame for Compustat Global begins later because of data availability. We then merge our database with variables constructed from CRSP data from 1986 to 2009 and variables constructed from Compustat Global Security Daily data from 1989 to 2009. Our resulting sample contains 25,538 loan facilities.

We begin by describing the primary variables used in our analysis. The dependent variable in our estimations are corporate loan interest rate spreads. Our measure of corporate loan spreads is Dealscan's All-In-Drawn spread which is interest rate on a corporate loan minus the LIBOR rate at the issue date. As stated by Santos and Winton (2010), Dealscan states that the All-In-Drawn spread is a measure of the "overall cost of the loan" that "takes into account, one time and recurring fees."

Our first main control variable is a dummy variable indicating whether a loan is originated by a borrower located in Europe or the United States. ${ }^{4}$ The dummy variable takes a value of 1 if the the borrower is located in Europe. The coefficient on this dummy variable is an estimate of difference in loan spreads paid by U.S. and European borrowers. Panel A of Table II provides counts of the number of loans originated by borrowers located in Europe or the U.S. in our data sample, and indicates that the majority of loans are originated by borrowers located in the U.S. Although our European sample is smaller than our U.S. sample, it is relatively large compared to those used by Carey and Nini (2007) and Houston et al. (2007). ${ }^{5}$ Panel B tabulates the number of loans originated by borrowers located in

\footnotetext{
${ }^{4}$ We also re-run all estimations with a dummy variable that indicates whether a loan is originated in the European market versus the U.S. market. However, classification is nearly identical because borrowers' typically obtain loans in their home market. The interpretation of all results are identical.

${ }^{5}$ In addition our sample is also limited by the availability of firm level control variables.
} 
each European country in our data sample, and indicates that the majority of European loans are originated by borrowers located in the United Kingdom, France, Germany, Spain, Netherlands, and Italy.

\section{[ PLACE TABLE II HERE ]}

Our next main control variables are estimates of borrowers' idiosyncratic and systematic stock return volatility. We construct our estimates of stock return volatility using data on borrowers' weekly stock returns. For U.S. firms we gather stock price data for CRSP for the final trading day of each week during a borrowers fiscal year and construct weekly returns using the formula used by CRSP to construct daily and monthly stock returns. ${ }^{6}$ For European firms, we gather stock price data from the Compustat Global Security Daily database for the final trading day of each week. The Compustat Global Security Daily database does not directly provide return data, so we construct weekly returns using the formula provided by Wharton Research Data Services (WRDS). ${ }^{7}$

We then use the constructed weekly returns to estimate the following CAPM regression model for each borrower's fiscal year:

$$
r_{i, t, j}^{s}-r_{t, j}^{f}=\beta_{i, t}\left(r_{t, j}^{m}-r_{t, j}^{f}\right)+\xi_{i, t, j}
$$

\footnotetext{
${ }^{6}$ The formula used to construct weekly stock returns for U.S. borrowers is $r_{i, t}^{s}=\frac{p_{i, t} f_{i t}-p_{i, t-1} f_{i, t-1}}{p_{i, t-1} f_{i, t-1}}$. In this formula, $r^{s}$, represents the stock return, the inverse of the cumulative split factor is denoted as $f$, and the price of firms shares are, $p$. The subscripts, $i$, and, $t$, refer to borrower and fiscal year respectively.

${ }^{7}$ The formula used to construct weekly stock returns for non-U.S. borrowers is is calculated in three steps. First, we convert all foreign stock prices into U.S. dollars. Second, we adjust prices by multiplying observed week-end prices by the daily total return factor and then divide this by the cumulative adjustment factor. We then calculate the weekly return as $r_{i, t}^{s}=\frac{p_{i, t}-p_{i, t}}{p_{i, t-1}}$. In the preceding formula, $r^{s}$, represents the stock return, the cumulative split factor is denoted as $f$, and the price of firms shares are, $p$. The subscripts, $i$, and, $t$, refer to borrower and fiscal year respectively.
} 
In equation $(7), r_{i, t, y}^{s}$, is the weekly stock return for firm, $i$, during week, $t$, in year, $j$. The risk free weight, $r_{t, j}^{f}$, is either the weekly 1 year treasury rate for U.S. firms or the weekly 1 year LIBOR rate for foreign firms. Also, $r_{t, j}^{m}$, is the return on market index $m$, during week, $t$, in year, $j$. Each firm's yearly CAPM beta is given by $\beta_{i, t}$, and $\xi_{i, t, y}$, is the idiosyncratic component of firm's weekly stock returns. An issue arises in deciding what proxy to use for firm's market index. For U.S. firms we follow convention and calculate a value weighted index for each week using all available returns in CRSP. For European firms, we use an estimate of the value weighted return on the stock exchange that each firm trades as a proxy for the relevant market portfolio. We include the returns for all available firms in the Compustat Global Security Daily database for each week available for each exchange in our estimates of the value weighted return. We drop all returns for exchanges with less than 100 available individual firm returns. Our estimate of systematic stock return volatility is, $\left(\widehat{\beta}_{i, t}\right) S t d\left(r_{t j}^{m}-r_{t, j}^{f}\right)$ which is the standard deviation of the excess return on the relevant market portfolio, multiplied by $\widehat{\beta}_{i, t}$, our estimate of each firm's CAPM beta. Our estimate of firm's idiosyncratic stock return volatility is $\operatorname{Std}\left(\xi_{i, t, j}\right)$ which is the yearly standard deviation of our estimate of each firm's weekly idiosyncratic stock returns. We annualize our measures of systematic and idiosyncratic stock return volatility by multiplying by $100 \times \sqrt{52}$.

Our next variables we discuss are our instrumental variables. We construct three instruments for equity volatility using quarterly financial statement data from Compustat and Compustat Global. The instruments we choose are based on relevance, and data availability. The first instrument is the yearly standard deviation of the ratio of borrowers' quarterly book equity to assets ratio. The second instrument is the yearly standard deviation of the ratio of borrowers' quarterly cash and short term investment to assets. The third instrument is the yearly standard deviation borrowers' quarterly total assets. 
We now discus our remaining control variables. For similar discussions and examples, see work by Santos (2011), Santos and Winton (2010), and Strahan (1999). For brevity, we do not discuss predictions regarding these variables' coefficient estimates, as these controls are standard in the literature and have been widely used in analysis similar to ours.

We construct multiple variables describing other non-price loan contract terms common in the literature. We construct a measure of loan size, which is the log of the loan facility amount in dollars. For term loans this would include the entire loan balance received by the borrower at origination, and for revolving lines of credit, this would include the amount of line of credit that the borrower has available for future use. We create an estimate of a loan's maturity length which is the log of the difference between a loan facility's stated maturity date and start date in days. We measure the size of the loan syndicate as the number of lenders. We include dummy variables that indicate whether a loan is secured, contains performance pricing provisions, or has general and financial covenants. Since information regarding whether a loan is secured is often missing, we set missing values of the secured indicator equal to zero and include an indicator for missing values. We also include dummy variables indicating loan type and purpose.

We construct multiple proxies for borrower's risk characteristics which we derive from firm's financial statement and stock price data. We include Tobin's average Q which is interpreted as the market value of firm's assets divided by the replacement value of firm's capital stock. Tobin's Average Q is calculated as the sum of total assets and market value of equity minus the sum of book value of common equity and deferred taxes, all divided by total assets. We include a proxy for leverage. Leverage is calculated as long term debt plus debt in current liabilities, all divided by total assets. We calculate a proxy for firm's cash stocks as the sum of cash and short term investments divided by total assets. We proxy for 
borrower size with the log of firm's total assets in millions. We have information on firm's debt ratings and include a proxy for Moody's senior unsecured debt rating at time of loan origination. We also include a dummy variable to indicate whether a firm has a debt rating or not. Debt ratings are provided directly by Dealscan. Finally, we create dummy variables for each year and 2-digit SIC codes.

We now briefly discuss basic summary statistics describing the variables in our data set which are located in Table III. We present statistics separately for European and U.S. subsamples and the total data sample. For each variable we report the mean, standard deviation, 25th and 75th percentiles. We briefly highlight the differences between the U.S. and European subsamples. First, loan spreads paid by the U.S. borrowers are roughly 25 basis points higher than those paid by European borrowers. In addition, the statistics indicate that U.S. borrowers' idiosyncratic equity volatility is roughly $15 \%$ higher on average compared to European firms, while systematic equity volatility is about the same for both U.S. and European firms. This is consistent with our expectation that U.S. borrowers pay higher loan spreads and have greater idiosyncratic equity volatility than European firms. Looking at the summary statistics for our instrumental variables, U.S. firms have greater cash and short term investment volatility and greater book equity volatility. However European firms have greater total asset volatility than U.S. firms, which we suspect is due to the fact that European firms are slightly larger than U.S. firms on average.

\section{[ PLACE TABLE III HERE ]}

Further examination reveals a few other differences between European and U.S. subsamples. U.S. firms have lower debt ratings but a greater portion of U.S. firms have debt ratings. We also see that loan syndicates have more lenders in Europe than in U.S. Finally 
a larger portion of loans are collateralized, contain covenants, and have performance pricing provisions in the U.S subsample. The remaining statistics indicate that U.S. and European subsamples have similar average values for Tobin's Q, leverage, loan maturity, and loan size.

\section{Results}

\section{A. Main Results}

We begin by describing our main results. We present out OLS estimates in Table IV, and we present our IV estimates in Tables V through VIII.

In the first column of Table IV, we include the full set of control variables but exclude idiosyncratic or systematic stock return volatility. The results indicate that the average loan spread received by European borrowers is about 37 basis points lower than those received by U.S. borrowers. In the second column we include the full set of control variables including idiosyncratic and systematic stock return volatility, and the results imply that the average loan spread received by European borrowers is about 29 basis points lower than those received by U.S. borrowers. Our OLS results are comparable to Carey and Nini (2007) who find a loan spread differential about 30 basis points and Houston et al. (2007) who find a loan spread differential about 40 basis points.

\section{[ PLACE TABLE IV HERE ]}

The results in the second column also indicate that there is a positive association between idiosyncratic equity volatility and loan spreads, and a negative association between systematic equity volatility and loan spreads. However, only the association between idiosyncratic 
equity volatility and loan spreads is statistically significant. Our estimates indicate that a one standard deviation increase in idiosyncratic equity volatility is associated with roughly a 22 basis point increase in loan spreads. Overall our OLS results suggest that controlling for idiosyncratic equity volatility influences the estimates of the loan spread difference paid by European and U.S. borrowers. However the results show that equity volatility cannot fully account for the loan spread difference.

We now discuss are main IV results presented in Table V. In the first column, we present estimation results with a full set of control variables, and we instrument both idiosyncratic and systematic equity volatility with our measures for quarterly balance sheet volatility. The results indicate that there is no longer any statistically significant difference in loan spreads paid by U.S. and European borrowers.

\section{[ PLACE TABLE V HERE ]}

These estimation results also show that the association between idiosyncratic equity volatility and loan spreads is about 5 times larger when compared to our OLS results. In addition, consistent with our OLS results we find that there is no statistically significant association between loan spreads and systematic volatility. The parameter estimate suggests that a one standard deviation increase in idiosyncratic equity volatility is associated with a 129 basis point increase in loan spreads.

In the second column we present results of a specification where we include all control variables except for systematic equity volatility, and the results are nearly identical to the results in the first column. The coefficient estimate implies that a one standard deviation increase in idiosyncratic equity volatility is associated with a 114 basis point increase in loan spreads. 
In order to preliminarily examine the robustness of our results, we re-estimate our IV model separately for both U.S. and European borrowers. We would like to examine whether idiosyncratic equity volatility is a determinant of loan spreads separately for both U.S and European borrowers, and whether our full sample results are overly influenced by either the U.S. or European sub-samples. The results for the U.S. and European sub-samples are located in the third and forth columns of Table $\mathrm{V}$ respectively. The results indicate that a one standard deviation increase in idiosyncratic equity volatility is associated with about 102 and 92 basis point increases in loan spreads for U.S. and European borrowers respectively. These results suggest that that our full sample results are not driven primarily by either U.S. or European sub-samples.

The first stage results for the models in Table $\mathrm{V}$ are presented in Table VI. In general as predicted these results indicate that our instrumental variables have a positive and statistically significant association with both of our measures of equity volatility. The only exceptions are that there is a negative association between total asset volatility and systematic equity volatility in the second column, and that cash and short term investment volatility does not have a statistically significant association with idiosyncratic equity volatility in the fifth column.

\section{[ PLACE TABLE VI HERE ]}

In addition, we note that in all of our specifications the p-values for the test of under identification rejects the null hypothesis that our model is under-identified. Also, the tests of over-identifying restrictions fail to reject the null hypothesis that our instruments are orthogonal to the error term. 


\section{B. Results for Additional Control Variables}

In this subsection we describe how our IV estimates differ from OLS estimates for our remaining control variables. We emphasize that if our OLS estimates of the association between equity volatility and syndicated loan spreads are biased and inconsistent, then all of the remaining estimates could be biased and inconsistent.

Our OLS results in Table IV are generally consistent with those found by previous research examining the determinants of syndicated loan spreads. We find that larger firm size, lower leverage, and more favorable debt ratings are all associated with lower loan spreads. The coefficient for borrowers' cash-to-assets is positive and statistically significant. This coefficient estimate appears to be at odds with intuition, as we would expect that borrowers with more cash and liquid assets should be able to more easily service debt payments. However studies by McLean (2011) and Riddick and Whited (2009) suggest that riskier firms

hold more cash. Consequently, the positive coefficient estimate could imply that we do not adequately control for volatility or risk in our OLS models.

Our results for loan terms are also consistent with prior research. The results indicate that larger loans and loans with longer maturities are associated with lower loan spreads. In addition, our results for loan contract terms indicate that loans with performance pricing and loans with financial covenants have lower spreads, and that secured loans and loans with general covenants have higher loan spreads. The number of lenders does not have have a statistically significant impact on cost of syndicated loans.

For multiple control variables our IV estimates differ markedly from our OLS estimates. Our IV estimates indicate that there is no longer any statistically significant association between borrower size and loan spreads. This contrasts with much of the corporate finance literature which assumes that larger size is associated with lower risk and asymmetric infor- 
mation problems.

In contrast to our OLS results, our IV results show that debt ratings no longer have a statistically significant association with loan spreads. Previous research suggests that borrowers with more favorable debt ratings are likely receive more favorable financing terms because debt ratings certify borrowers' credit worthiness and help to mitigate asymmetric information and credit risk problems. However, our IV results suggest that debt ratings do not have explanatory power for loan spreads after controlling for volatility.

The coefficient on borrowers' cash and short term investment is negative and statistically significant in our IV estimations. This contrasts with the positive and statistically significant coefficient found in our OLS specification. Likewise compared to OLS results the coefficient on leverage is also smaller in the IV results. These OLS coefficient estimates are likely biased upward due to the positive correlation between idiosyncratic equity volatility and these variables, and because the OLS coefficient estimate for idiosyncratic volatility is downward biased. The first stage results in Table VI support this claim because they show that cash and short term investments and leverage have a strong positive association with idiosyncratic equity volatility, and leverage.

Certain coefficients for loan contract terms also change. The estimated coefficients for corporate loan maturity and the secured loan indicator also differ between our OLS and IV results. The coefficient on loan maturity is no longer statistically significant in our IV results, and the coefficient on the secured indicator is in our IV results is about half of the OLS estimates. Otherwise, the parameter estimates on the remaining control variables are largely unchanged. 


\section{Robustness Checks}

In this section we present multiple robustness checks to further assess the validity of our estimation results. The second stage results are presented in Table VII, and the first stage results are presented in Table VIII. First, we use each of our measures of balance sheet volatility to estimate exactly identified IV models. We present these results in the first three columns of Table VII. The results indicate that the coefficient estimates for idiosyncratic equity volatility are quantitatively similar to the results presented in Table V.

\section{[ PLACE TABLE VII HERE ]}

Inspection of the IV estimations in Table V and the first three columns of Table VII show that both the European dummy variable and borrower size are not statistically significant in the second stage estimates, and the results in Table VI and the first three columns in Table VIII indicate that these variables are statistically significant in the first stage estimates. If these variables are uncorrelated with the residuals in our empirical model, then we expect that these variables may be suitable instrumental variables for equity volatility. Therefore, if this is the case, then using European dummy variable and borrower size as instrumental variables should provide estimates that are similar to our previous IV results.

We present these results in forth through sixth columns of Table VII. In the forth column, we include only total assets as an instrument; in the fifth column we include our balance sheet volatility indicators and total assets as instruments; and in the sixth column we include European dummy as the only instrument. The results in the forth and fifth columns are again quantitatively similar to our previous IV results. 


\section{[ PLACE TABLE VIII HERE ]}

In the sixth column, when the European dummy variable is the only an instrument for idiosyncratic equity volatility, the estimated coefficient on idiosyncratic equity volatility is again comparable to previous results. This provides additional confirmation that the observed difference in loan spreads paid by U.S. and European borrowers in our OLS model and previous research can be accounted for by U.S. borrowers' greater idiosyncratic equity volatility.

Taken together, our robustness checks indicate that multiple sets of instrumental variables generate similar coefficient estimates of the empirical association between equity volatility and corporate loan spreads. We suggest that these results imply that our primary results presented in Table $\mathrm{V}$ are not due to luck, data mining, or any particular bias generated by a particular instrumental variable. In addition, our results imply that multiple instrumental variables can be used to identify an association between idiosyncratic equity volatility and corporate loan spreads that accounts for the difference in average loans spreads between loans originated by U.S. and European borrowers. We also point out that in all of our robustness checks, that we fail to reject the null hypothesis that the instruments are correlated with the residuals.

\section{Conclusion}

This paper examines whether idiosyncratic equity volatility can account for the average difference in corporate loan spreads paid by U.S. and European borrowers observed by previous research. We present evidence that OLS estimates of the association between loan spreads and systematic and idiosyncratic equity volatility are likely biased and inconsistent. We use 
an instrumental variable estimator that can potentially identify consistent estimates of the association between loan spreads and equity volatility. Our main IV results indicate that there is no statistically significant difference in corporate loan spreads paid by U.S. and European borrowers, and that OLS estimates of the association between idiosyncratic equity volatility and loan spreads is downward biased by a factor of about 5 .

\section{References}

Bartram, S. M., G. Brown, and R. M. Stulz (2009). Why Do Foreign Firms Have Less Idiosyncratic Risk than U.S. Firms? NBER Working Papers 14931, National Bureau of Economic Research, Inc.

Bekaert, G., R. J. Hodrick, and X. Zhang (2012). Aggregate Idiosyncratic Volatility. Journal of Financial and Quantitative Analysis (forthcoming).

Cairns, A. J. G. (2004). Interest Rate Models: An Introduction. (Princeton University Press).

Campbell, J. Y. and G. B. Taksler (2003). Equity Volatility and Corporate Bond Yields. Journal of Finance 58(6), 2321-2350.

Carey, M. and G. Nini (2007). Is the Syndicated Loan Market Gloablly Integrated? The Journal of Finance 33(3), 389-404.

Gilchrist, S., J. Sim, and E. Zakrajšsek (2010). Uncertainty, Financial Frictions, and Investment Dynamics.

Houston, J., J. Itzkowitz, and A. Naranjo (2007). Borrowing beyond Borders: The Geography and Pricing of Syndicated Bank Loans. Working paper, University of Florida. 
Lando, D. (2004). Credit Risk Modeling: Theory and Applications. (Princeton University Press).

McLean, D. R. (2011). Share Issuance and Cash Savings. Journal of Financial Economics $99(3), 693-715$.

McNeil, A. J., R. Frey, and P. Embrechts (2005). Quantitative Risk Management: Concepts, Techniques, and Tools. (Princeton University Press).

Merton, R. C. (1974). On the Pricing of Corporate Debt: The Risk Structure of Interest Rates. Journal of Finance 29(2), 449-70.

Riddick, L. A. and T. M. Whited (2009). The Corporate Propensity to Save. The Journal of Finance 64(4), 1729-1766.

Santos, J. (2011). Bank Corporate Loan Pricing Following the Subprime Crisis. The Review of Financial Studies Forthcoming.

Santos, J. and A. Winton (2010). Bank Capital, Borrower Power, and Loan Rates. Technical report.

Shumway, T. (2001). Forecasting Bankruptcy More Accurately: A Simple Hazard Model. Journal of Business 74 (1), 101-24.

Strahan, P. (1999). Borrower Risk and the Price and Nonprice Terms of Bank Loans. Working paper, Federal Reserve Bank of New York, Banking Studies Function. 
Table I: Borrower Region and Market of Syndication

This table tabulates borrowers' location against loans' market of syndication. "Other" market of syndication includes Africa, Asia Pacific, Eastern Europe/Russia, Latin America/Caribbean, and Unknown.

\begin{tabular}{l|cccc}
\hline \hline & \multicolumn{4}{|c}{ Market of Syndication } \\
Borrower Region & United States & Western Europe & Other & Total \\
\hline United States & 23,816 & 52 & 44 & 23,912 \\
Western Europe & 46 & 1,569 & 11 & 1,626 \\
\hline Total & 23,862 & 1,621 & 55 & 25,538 \\
\hline \hline
\end{tabular}




\section{Table II: Distribution of Borrower Location}

This table tabulates the number of loans by borrower location. Panel A provides counts of the number of loans originated by borrowers located in Europe or the U.S. Panel B tabulates the number of loans originated by borrowers located in each European country in our data sample.

Panel A: Number of Loans by Borrower Location

\begin{tabular}{lcc}
\hline & Frequency & Percentage \\
\hline United States & 23,816 & 93.63 \\
Europe & 1,626 & 6.37 \\
\hline
\end{tabular}

Panel B: Number of Loans by Borrower Country for Firms Located in Europe

\begin{tabular}{lcc}
\hline & Frequency & Percentage \\
\hline United Kingdom & 645 & 39.67 \\
France & 215 & 13.22 \\
Germany & 188 & 11.56 \\
Spain & 146 & 8.98 \\
Netherlands & 114 & 7.01 \\
Italy & 108 & 6.64 \\
Sweden & 53 & 3.26 \\
Ireland & 47 & 2.89 \\
Norway & 34 & 2.09 \\
Finland & 20 & 1.23 \\
Belgium & 16 & 0.98 \\
Denmark & 12 & 0.74 \\
Greece & 10 & 0.62 \\
Luxembourg & 8 & 0.49 \\
Portugal & 4 & 0.25 \\
Switzerland & 3 & 0.18 \\
Austria & 2 & 0.12 \\
Cyprus & 1 & 0.06 \\
\hline \hline
\end{tabular}




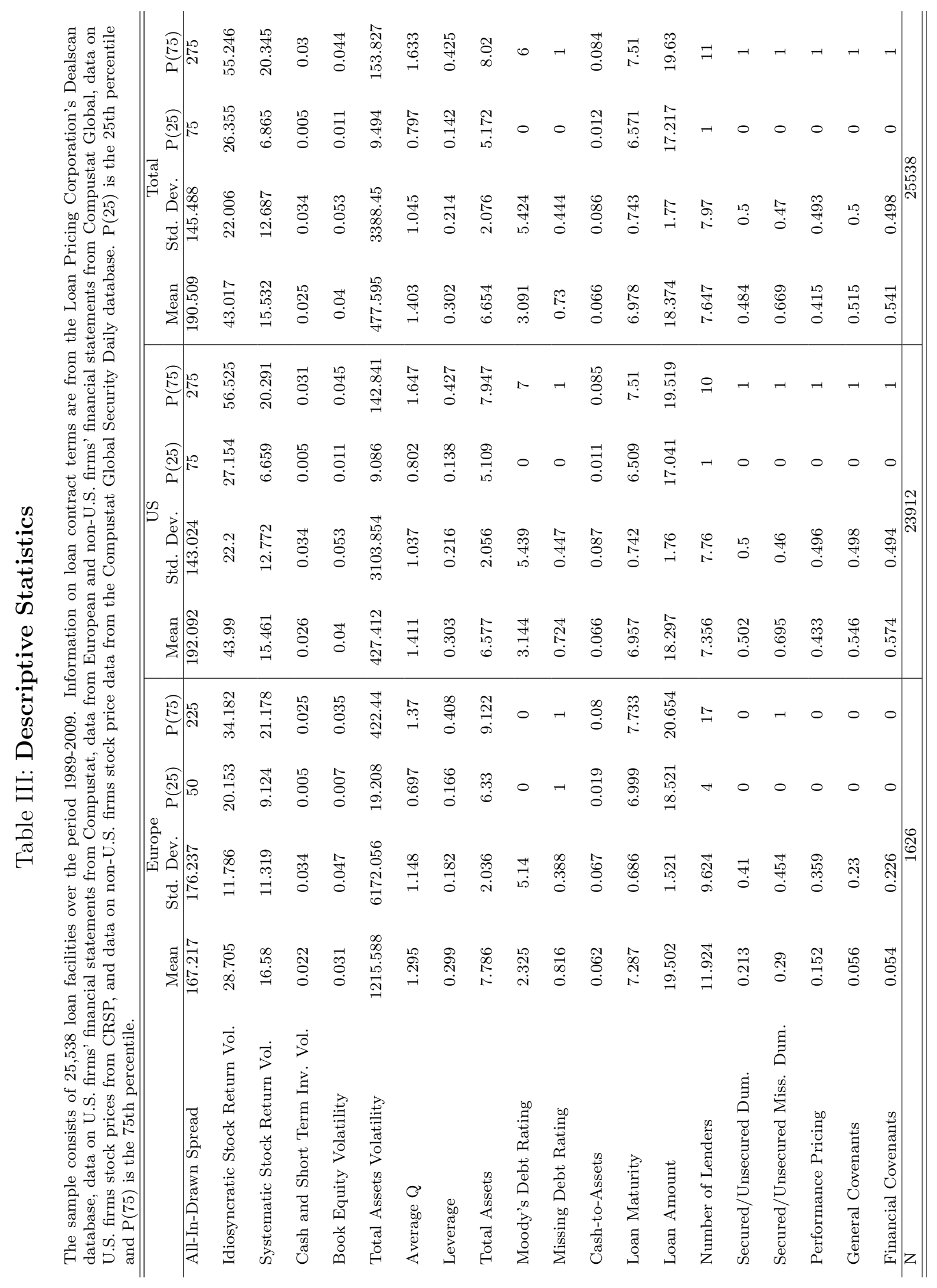




\section{Table IV: OLS}

The dependent variable in OLS regressions is the all-in-drawn spread on the loan. Loan type, loan purpose, 2-digit SIC dummies, and year dummies are included in the regressions but are omitted from the table. All standard errors are clustered at the firm level and are reported below the coefficient estimates.

\begin{tabular}{|c|c|c|}
\hline & $\begin{array}{l}\text { Without } \\
\text { Volatility }\end{array}$ & $\begin{array}{c}\text { With } \\
\text { Volatility }\end{array}$ \\
\hline European Market & $-36.971^{* * *}$ & $-28.921^{* * *}$ \\
\hline & 4.675 & 4.554 \\
\hline Average Q & $-11.255^{* * *}$ & $-11.986^{* * *}$ \\
\hline & 0.924 & 0.908 \\
\hline Leverage & $\begin{array}{c}81.190^{* * *} \\
5.873\end{array}$ & $\begin{array}{c}72.565^{* * *} \\
5.684\end{array}$ \\
\hline Total Assets & $\begin{array}{c}-10.771^{* * *} \\
1.047\end{array}$ & $\begin{array}{c}-8.584 * * * \\
1.036\end{array}$ \\
\hline Moody's Debt Rating & $\begin{array}{c}-6.440^{* * *} \\
0.602\end{array}$ & $\begin{array}{c}-5.336^{* * *} \\
0.571\end{array}$ \\
\hline Missing Debt Rating & $\begin{array}{c}-70.941^{* * *} \\
7.681\end{array}$ & $\begin{array}{c}-58.860^{* * *} \\
7.331\end{array}$ \\
\hline Cash-to-Assets & $\begin{array}{c}49.161^{* * *} \\
12.108\end{array}$ & $\begin{array}{c}30.452^{* *} \\
12.007\end{array}$ \\
\hline Loan Maturity & $\begin{array}{c}-10.432^{* * *} \\
2.259\end{array}$ & $\begin{array}{c}-8.641^{* * *} \\
2.242\end{array}$ \\
\hline Loan Amount & $\begin{array}{c}-18.038^{* * *} \\
0.993\end{array}$ & $\begin{array}{c}-16.848^{* * *} \\
0.984\end{array}$ \\
\hline Number of Lenders & $\begin{array}{l}0.126 \\
0.128\end{array}$ & $\begin{array}{l}0.112 \\
0.124\end{array}$ \\
\hline Secured/Unsecured Dummy & $\begin{array}{c}63.817^{* * *} \\
2.315\end{array}$ & $\begin{array}{c}57.481^{* * *} \\
2.272\end{array}$ \\
\hline Secured/Unsecured Missing Dummy & $\begin{array}{c}-5.441^{* *} \\
2.285\end{array}$ & $\begin{array}{c}-5.022^{* *} \\
2.232\end{array}$ \\
\hline Performance Pricing & $\begin{array}{c}-35.585^{* * *} \\
2.642\end{array}$ & $\begin{array}{c}-32.934^{* * *} \\
2.554\end{array}$ \\
\hline General Covenants & $\begin{array}{c}19.583^{* * *} \\
3.337\end{array}$ & $\begin{array}{c}20.349^{* * *} \\
3.268\end{array}$ \\
\hline Financial Covenants & $\begin{array}{c}-10.897^{* * *} \\
3.227\end{array}$ & $\begin{array}{c}-11.793^{* * *} \\
3.153\end{array}$ \\
\hline Idiosyncratic Stock Return Vol. & & $\begin{array}{c}1.033^{* * *} \\
0.060\end{array}$ \\
\hline Systematic Stock Return Vol. & & $\begin{array}{c}-0.003 \\
0.091\end{array}$ \\
\hline$\overline{\mathrm{N}}$ & 25538 & 25538 \\
\hline
\end{tabular}




\section{Table V: Main Instrumental Variable Results}

The dependent variable in IV regressions is the all-in-drawn spread on the loan. Loan type, loan purpose, 2-digit SIC dummies, and year dummies are included in the regressions but are omitted from the table. All standard errors are clustered at the firm level and are reported below the coefficient estimates. The instruments used for each column are specified in the Instruments Used panel. Under-Id test has the null hypothesis that the equation is under identified, so rejection of this test implies that the excluded instruments are relevant, meaning correlated with the endogenous regressors. Null Hypothesis for Hansen $J$ test is that the instruments are valid instruments, i.e., uncorrelated with the error term, and that the excluded instruments are correctly excluded from the estimated equation. First and second columns use the whole sample, third column is the sample for U.S., and forth column is for the European sample.

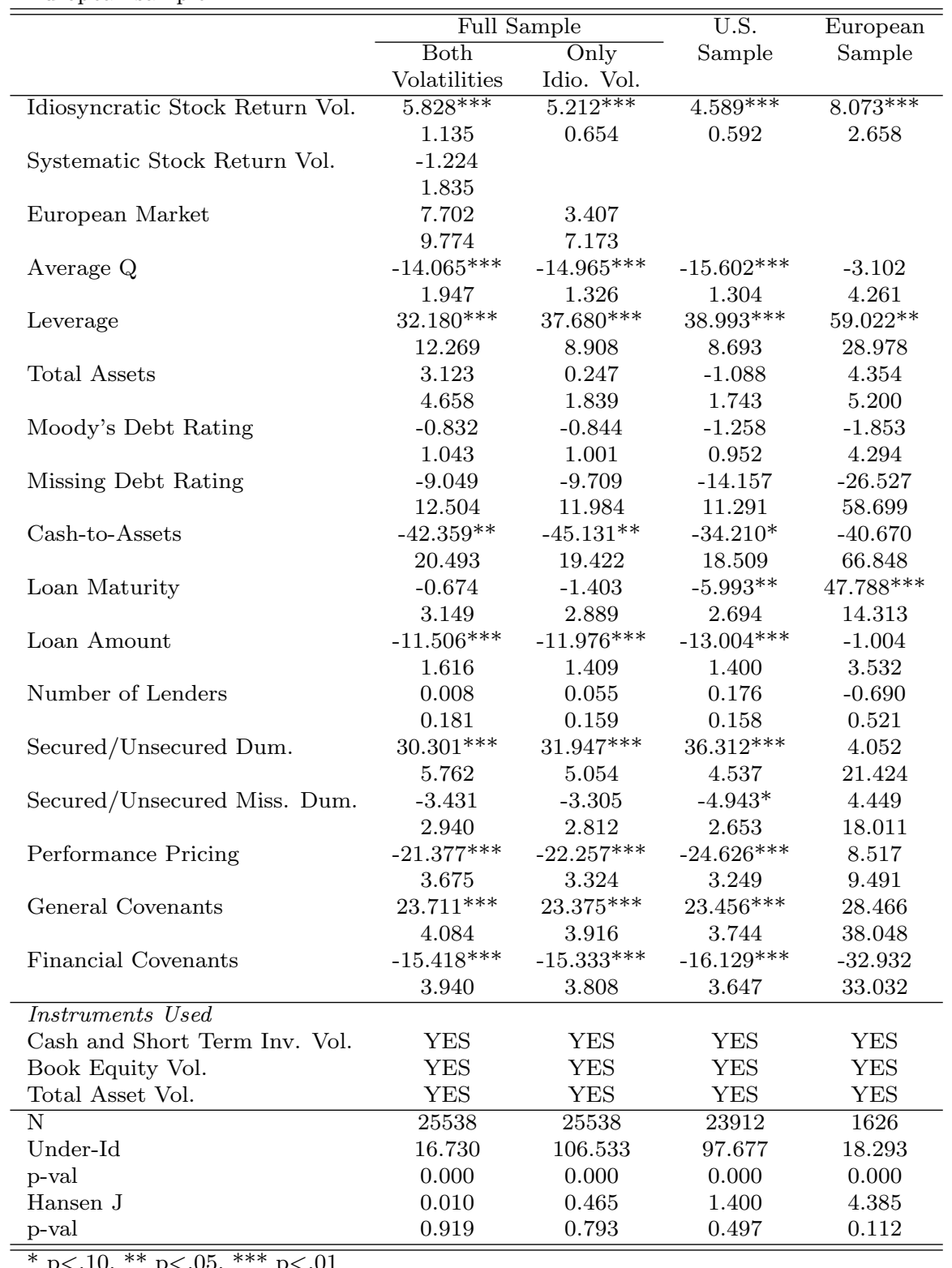




\section{Table VI: First Stage Results for Main Instrumental Variable Estimation}

The dependent variable in the first stage regressions is either the idiosyncratic stock return volatility or the systematic stock return volatility, and is specified under the column number. Loan type, loan purpose, 2-digit SIC dummies, and year dummies are included in the regressions but are omitted from the table. All standard errors are clustered at the firm level and are reported below the coefficient estimates. The instruments used for each column are specified in the Instruments Used panel. First through third columns use the whole sample, forth column is the sample for U.S., and forth column is for the European sample.

\begin{tabular}{|c|c|c|c|c|c|}
\hline & \multicolumn{2}{|c|}{$\begin{array}{c}\text { Full Sample } \\
\text { Both Volatilities }\end{array}$} & \multirow{2}{*}{$\begin{array}{c}\text { Full Sample } \\
\text { Only Idio. Vol. }\end{array}$} & \multirow[t]{2}{*}{$\begin{array}{c}\text { U.S. } \\
\text { Sample }\end{array}$} & \multirow[t]{2}{*}{$\begin{array}{c}\text { European } \\
\text { Sample }\end{array}$} \\
\hline & Idio. Vol. & Syst. Vol. & & & \\
\hline \multicolumn{6}{|l|}{ Instruments Used } \\
\hline Cash and Short Term Inv. Vol. & $\begin{array}{c}21.012^{* * *} \\
6.575\end{array}$ & $\begin{array}{c}16.849^{* * *} \\
4.069\end{array}$ & $\begin{array}{c}21.012^{* * *} \\
6.575\end{array}$ & $\begin{array}{c}23.423^{* * *} \\
6.962\end{array}$ & $\begin{array}{c}-13.906 \\
11.489\end{array}$ \\
\hline \multirow[t]{2}{*}{ Book Equity Volatility } & $28.202^{* * *}$ & $17.557^{* * *}$ & $28.202^{* * *}$ & $27.777^{* * *}$ & $36.588^{* * *}$ \\
\hline & 4.069 & 2.648 & 4.069 & 4.222 & 8.317 \\
\hline \multirow[t]{2}{*}{ Total Assets Volatility } & $0.000^{* * *}$ & $-0.000^{* * *}$ & $0.000^{* * *}$ & $0.000^{* *}$ & $0.000^{*}$ \\
\hline & 0.000 & 0.000 & 0.000 & 0.000 & 0.000 \\
\hline \multirow[t]{2}{*}{ European Market } & $-7.969^{* * *}$ & -0.708 & $-7.969^{* * *}$ & & \\
\hline & 0.661 & 0.457 & 0.661 & & \\
\hline \multirow[t]{2}{*}{ Average $\mathrm{Q}$} & $0.398^{*}$ & $0.879 * * *$ & $0.398^{*}$ & $0.577^{* *}$ & $-0.990^{* *}$ \\
\hline & 0.214 & 0.120 & 0.214 & 0.228 & 0.426 \\
\hline \multirow[t]{2}{*}{ Leverage } & $7.874^{* * *}$ & -0.534 & $7.874^{* * *}$ & $8.665^{* * *}$ & -0.588 \\
\hline & 1.200 & 0.634 & 1.200 & 1.267 & 2.731 \\
\hline \multirow[t]{2}{*}{ Total Assets } & $-2.076^{* * *}$ & $1.483^{* * *}$ & $-2.076^{* * *}$ & $-2.144^{* * *}$ & $-1.346^{* * *}$ \\
\hline & 0.188 & 0.103 & 0.188 & 0.210 & 0.274 \\
\hline \multirow[t]{2}{*}{ Moody's Debt Rating } & $-1.072^{* * *}$ & $-0.497 * * *$ & $-1.072^{* * *}$ & $-1.085^{* * *}$ & $-1.321 * * *$ \\
\hline & 0.116 & 0.059 & 0.116 & 0.122 & 0.331 \\
\hline \multirow[t]{2}{*}{ Missing Debt Rating } & $-11.832^{* * *}$ & $-4.999 * * *$ & $-11.832^{* * *}$ & $-11.763^{* * *}$ & $-18.001^{* * *}$ \\
\hline & 1.450 & 0.741 & 1.450 & 1.510 & 4.222 \\
\hline \multirow[t]{2}{*}{ Cash-to-Assets } & $12.758^{* * *}$ & $7.690^{* * *}$ & $12.758^{* * *}$ & $12.215^{* * *}$ & $10.107^{*}$ \\
\hline & 2.483 & 1.513 & 2.483 & 2.604 & 5.842 \\
\hline \multirow[t]{2}{*}{ Loan Maturity } & $-1.638^{* * *}$ & -0.224 & $-1.638^{* * *}$ & $-1.542^{* * *}$ & $-1.243^{* *}$ \\
\hline & 0.307 & 0.181 & 0.307 & 0.326 & 0.580 \\
\hline \multirow[t]{2}{*}{ Loan Amount } & $-1.108 * * *$ & $-0.213^{* *}$ & $-1.108 * * *$ & $-1.150^{* * *}$ & $-0.717^{* *}$ \\
\hline & 0.165 & 0.097 & 0.165 & 0.180 & 0.284 \\
\hline \multirow[t]{2}{*}{ Number of Lenders } & 0.009 & $-0.034^{* *}$ & 0.009 & 0.016 & -0.006 \\
\hline & 0.026 & 0.015 & 0.026 & 0.029 & 0.046 \\
\hline \multirow[t]{2}{*}{ Secured/Unsecured Dum. } & $5.742^{* * *}$ & $1.655^{* * *}$ & $5.742^{* * *}$ & $5.544^{* * *}$ & $3.722^{* * *}$ \\
\hline & 0.429 & 0.251 & 0.429 & 0.445 & 1.296 \\
\hline \multirow[t]{2}{*}{ Secured/Unsecured Miss. Dum. } & -0.384 & -0.304 & -0.384 & -0.124 & $-2.760 * *$ \\
\hline & 0.424 & 0.260 & 0.424 & 0.441 & 1.164 \\
\hline \multirow[t]{2}{*}{ Performance Pricing } & $-2.425^{* * *}$ & $-0.517^{* *}$ & $-2.425^{* * *}$ & $-2.516^{* * *}$ & -0.693 \\
\hline & 0.421 & 0.238 & 0.421 & 0.442 & 0.819 \\
\hline \multirow[t]{2}{*}{ General Covenants } & -0.774 & -0.258 & -0.774 & -0.613 & 3.042 \\
\hline & 0.544 & 0.340 & 0.544 & 0.555 & 1.923 \\
\hline \multirow[t]{2}{*}{ Financial Covenants } & $0.977^{*}$ & $0.527^{*}$ & $0.977^{*}$ & 0.840 & 0.425 \\
\hline & 0.530 & 0.314 & 0.530 & 0.538 & 1.758 \\
\hline $\mathrm{N}$ & 25538 & 25538 & 25538 & 23912 & 1626 \\
\hline
\end{tabular}




\section{Table VII: Instrumental Variable Results for Robustness Checks}

The dependent variable in IV regressions is the all-in-drawn spread on the loan. Loan type, loan purpose, 2-digit SIC dummies, and year dummies are included in the regressions but are omitted from the table. All standard errors are clustered at the firm level and are reported below the coefficient estimates. The instruments used for each column are specified in the Instruments Used panel. Under-Id test has the null hypothesis that the equation is under identified, so rejection of this test implies that the excluded instruments are relevant, meaning correlated with the endogenous regressors. Null Hypothesis for Hansen $J$ test is that the instruments are valid instruments, i.e., uncorrelated with the error term, and that the excluded instruments are correctly excluded from the estimated equation.

\begin{tabular}{|c|c|c|c|c|c|c|}
\hline & $(1)$ & $(2)$ & (3) & $(4)$ & $(5)$ & $(6)$ \\
\hline \multirow[t]{2}{*}{ Idiosyncratic Stock Return Vol. } & $4.920^{* * *}$ & $5.097^{* * *}$ & $6.070^{* * *}$ & $5.099^{* * *}$ & $5.146^{* * *}$ & $4.745^{* * *}$ \\
\hline & 1.022 & 0.724 & 1.559 & 0.574 & 0.431 & 0.626 \\
\hline \multirow[t]{2}{*}{ European Market } & 1.362 & 2.745 & 10.328 & 2.763 & 2.870 & \\
\hline & 9.627 & 7.368 & 13.687 & 6.554 & 5.937 & \\
\hline \multirow{2}{*}{ Average Q } & $-14.753^{* * *}$ & $-14.879 * * *$ & $-15.571^{* * *}$ & $-14.881^{* * *}$ & $-14.937 * * *$ & $-14.629 * * *$ \\
\hline & 1.402 & 1.339 & 1.759 & 1.364 & 1.304 & 1.298 \\
\hline \multirow[t]{2}{*}{ Leverage } & $40.137^{* * *}$ & $38.656^{* * *}$ & $30.534^{* *}$ & $38.636^{* * *}$ & $38.259^{* * *}$ & $41.595^{* * *}$ \\
\hline & 11.092 & 9.186 & 15.133 & 8.304 & 7.779 & 8.758 \\
\hline \multirow[t]{2}{*}{ Total Assets } & -0.380 & -0.005 & 2.051 & & & -0.749 \\
\hline & 2.525 & 1.929 & 3.523 & & & 1.733 \\
\hline \multirow[t]{2}{*}{ Moody's Debt Rating } & -1.174 & -0.984 & 0.058 & -0.981 & -0.907 & -1.361 \\
\hline & 1.310 & 1.055 & 1.830 & 0.993 & 0.882 & 0.952 \\
\hline \multirow[t]{2}{*}{ Missing Debt Rating } & -13.346 & -11.268 & 0.126 & -11.241 & -10.458 & -15.392 \\
\hline & 15.174 & 12.498 & 20.665 & 11.513 & 10.575 & 11.608 \\
\hline \multirow[t]{2}{*}{ Cash-to-Assets } & $-40.085^{*}$ & $-43.305^{* *}$ & $-60.960^{*}$ & $-43.347 * *$ & $-44.044^{* *}$ & $-36.914^{*}$ \\
\hline & 23.960 & 20.018 & 33.270 & 19.176 & 17.604 & 18.875 \\
\hline \multirow[t]{2}{*}{ Loan Maturity } & -1.902 & -1.594 & 0.093 & -1.590 & -1.544 & -2.205 \\
\hline & 3.218 & 2.907 & 3.919 & 2.726 & 2.689 & 2.702 \\
\hline \multirow[t]{2}{*}{ Loan Amount } & $-12.369 * * *$ & $-12.164^{* * *}$ & $-11.042^{* * *}$ & $-12.161^{* * *}$ & $-11.990 * * *$ & $-12.570^{* * *}$ \\
\hline & 1.656 & 1.476 & 2.152 & 1.664 & 1.401 & 1.402 \\
\hline \multirow[t]{2}{*}{ Number of Lenders } & 0.061 & 0.059 & 0.046 & 0.059 & 0.059 & 0.063 \\
\hline & 0.157 & 0.159 & 0.176 & 0.157 & 0.155 & 0.152 \\
\hline \multirow[t]{2}{*}{ Secured/Unsecured Dum. } & $33.628^{* * *}$ & $32.538^{* * *}$ & $26.566^{* * *}$ & $32.524^{* * *}$ & $32.303^{* * *}$ & $34.700 * * *$ \\
\hline & 6.859 & 5.386 & 10.259 & 5.067 & 4.292 & 4.890 \\
\hline \multirow[t]{2}{*}{ Secured/Unsecured Miss. Dum. } & -3.443 & -3.371 & -2.976 & -3.370 & -3.328 & -3.514 \\
\hline & 2.792 & 2.796 & 3.122 & 2.800 & 2.797 & 2.689 \\
\hline \multirow[t]{2}{*}{ Performance Pricing } & $-22.956^{* * *}$ & $-22.501^{* * *}$ & $-20.003^{* * *}$ & $-22.495^{* * *}$ & $-22.410^{* * *}$ & $-23.405^{* * *}$ \\
\hline & 3.869 & 3.382 & 5.118 & 3.296 & 3.114 & 3.244 \\
\hline \multirow[t]{2}{*}{ General Covenants } & $23.234^{* * *}$ & $23.365^{* * *}$ & $24.088^{* * *}$ & $23.367^{* * *}$ & $23.331^{* * *}$ & $23.104^{* * *}$ \\
\hline & 3.912 & 3.896 & 4.389 & 3.900 & 3.891 & 3.745 \\
\hline \multirow[t]{2}{*}{ Financial Covenants } & $-15.172^{* * *}$ & $-15.327^{* * *}$ & $-16.172^{* * *}$ & $-15.329 * * *$ & $-15.320^{* * *}$ & $-15.020^{* * *}$ \\
\hline & 3.818 & 3.788 & 4.350 & 3.847 & 3.795 & 3.761 \\
\hline \multicolumn{7}{|l|}{ Instruments Used } \\
\hline Cash and Short Term Inv. Vol. & YES & & & & YES & \\
\hline Book Equity Vol. & & YES & & & YES & \\
\hline Total Asset Vol. & & & YES & & YES & \\
\hline Total Assets & & & & YES & YES & \\
\hline European Dummy & & & & & & YES \\
\hline $\mathrm{N}$ & 25538 & 25538 & 25538 & 25538 & 25538 & 25538 \\
\hline Under-Id & 44.028 & 77.858 & 23.813 & 110.192 & 205.481 & 115.689 \\
\hline p-val & 0.000 & 0.000 & 0.000 & 0.000 & 0.000 & 0.000 \\
\hline Hansen J & & & & & 0.483 & \\
\hline p-val & & & & & 0.923 & \\
\hline
\end{tabular}




\section{Table VIII: First Stage Results for Robustness Checks}

The dependent variable in the first stage regressions is the idiosyncratic stock return volatility. Loan type, loan purpose, 2-digit SIC dummies, and year dummies are included in the regressions but are omitted from the table. All standard errors are clustered at the firm level and are reported below the coefficient estimates. The instruments used for each column are specified in the Instruments Used panel.

\begin{tabular}{|c|c|c|c|c|c|c|}
\hline & $(1)$ & (2) & (3) & (4) & (5) & (6) \\
\hline \multirow[t]{2}{*}{ Cash and Short Term Inv. Vol. } & $40.574^{* * *}$ & & & & $21.012^{* * *}$ & \\
\hline & 6.104 & & & & 6.575 & \\
\hline \multirow[t]{2}{*}{ Book Equity Volatility } & & $33.601 * * *$ & & & $28.202^{* * *}$ & \\
\hline & & 3.825 & & & 4.069 & \\
\hline \multirow[t]{2}{*}{ Total Assets Volatility } & & & $0.000 * * *$ & & $0.000 * * *$ & \\
\hline & & & 0.000 & & 0.000 & \\
\hline \multirow[t]{2}{*}{ European Market } & $-7.912^{* * *}$ & $-7.865^{* * *}$ & $-7.862^{* * *}$ & $-7.792^{* * *}$ & $-7.969 * * *$ & $-7.792^{* * *}$ \\
\hline & 0.668 & 0.663 & 0.665 & 0.670 & 0.661 & 0.670 \\
\hline \multirow[t]{2}{*}{ Average Q } & $0.553^{* * *}$ & $0.436^{* *}$ & $0.711^{* * *}$ & $0.711^{* * *}$ & $0.398^{*}$ & $0.711^{* * *}$ \\
\hline & 0.210 & 0.213 & 0.207 & 0.207 & 0.214 & 0.207 \\
\hline \multirow[t]{2}{*}{ Leverage } & $8.976^{* * *}$ & $7.376^{* * *}$ & $8.366^{* * *}$ & $8.345^{* * *}$ & $7.874^{* * *}$ & $8.345^{* * *}$ \\
\hline & 1.192 & 1.184 & 1.181 & 1.181 & 1.200 & 1.181 \\
\hline \multirow[t]{2}{*}{ Total Assets } & $-2.079 * * *$ & $-1.905^{* * *}$ & $-2.312^{* * *}$ & $-2.112 * * *$ & $-2.076^{* * *}$ & $-2.112^{* * *}$ \\
\hline & 0.178 & 0.180 & 0.188 & 0.180 & 0.188 & 0.180 \\
\hline \multirow[t]{2}{*}{ Moody's Debt Rating } & $-1.059 * * *$ & $-1.058^{* * *}$ & $-1.093^{* * *}$ & $-1.071^{* * *}$ & $-1.072^{* * *}$ & $-1.071 * * *$ \\
\hline & 0.117 & 0.117 & 0.116 & 0.117 & 0.116 & 0.117 \\
\hline \multirow[t]{2}{*}{ Missing Debt Rating } & $-11.621^{* * *}$ & $-11.616^{* * *}$ & $-12.023^{* * *}$ & $-11.707^{* * *}$ & $-11.832^{* * *}$ & $-11.707 * * *$ \\
\hline & 1.452 & 1.451 & 1.451 & 1.454 & 1.450 & 1.454 \\
\hline \multirow[t]{2}{*}{ Cash-to-Assets } & $11.513^{* * *}$ & $15.843^{* * *}$ & $18.113^{* * *}$ & $18.141^{* * *}$ & $12.758^{* * *}$ & $18.141 * * *$ \\
\hline & 2.459 & 2.303 & 2.328 & 2.326 & 2.483 & 2.326 \\
\hline \multirow[t]{2}{*}{ Loan Maturity } & $-1.682^{* * *}$ & $-1.646^{* * *}$ & $-1.741^{* * *}$ & $-1.734^{* * *}$ & $-1.638^{* * *}$ & $-1.734^{* * *}$ \\
\hline & 0.308 & 0.307 & 0.309 & 0.309 & 0.307 & 0.309 \\
\hline \multirow[t]{2}{*}{ Loan Amount } & $-1.143^{* * *}$ & $-1.208^{* * *}$ & $-1.042^{* * *}$ & $-1.152^{* * *}$ & $-1.108^{* * *}$ & $-1.152^{* * *}$ \\
\hline & 0.164 & 0.164 & 0.167 & 0.166 & 0.165 & 0.166 \\
\hline \multirow[t]{2}{*}{ Number of Lenders } & 0.014 & 0.009 & 0.012 & 0.013 & 0.009 & 0.013 \\
\hline & 0.026 & 0.026 & 0.026 & 0.026 & 0.026 & 0.026 \\
\hline \multirow[t]{2}{*}{ Secured/Unsecured Dummy } & $5.939 * * *$ & $5.886 * * *$ & $6.032 * * *$ & $6.137^{* * *}$ & $5.742 * * *$ & $6.137^{* * *}$ \\
\hline & 0.431 & 0.430 & 0.433 & 0.432 & 0.429 & 0.432 \\
\hline \multirow[t]{2}{*}{ Secured/Unsecured Missing Dummy } & -0.444 & -0.368 & -0.394 & -0.406 & -0.384 & -0.406 \\
\hline & 0.426 & 0.424 & 0.426 & 0.426 & 0.424 & 0.426 \\
\hline \multirow[t]{2}{*}{ Performance Pricing } & $-2.506^{* * *}$ & $-2.426^{* * *}$ & $-2.577^{* * *}$ & $-2.567^{* * *}$ & $-2.425^{* * *}$ & $-2.567^{* * *}$ \\
\hline & 0.421 & 0.422 & 0.422 & 0.422 & 0.421 & 0.422 \\
\hline \multirow[t]{2}{*}{ General Covenants } & -0.717 & -0.863 & -0.669 & -0.742 & -0.774 & -0.742 \\
\hline & 0.543 & 0.544 & 0.546 & 0.546 & 0.544 & 0.546 \\
\hline \multirow[t]{2}{*}{ Financial Covenants } & $0.891^{*}$ & $0.983^{*}$ & 0.870 & 0.869 & $0.977^{*}$ & 0.869 \\
\hline & 0.534 & 0.533 & 0.538 & 0.539 & 0.530 & 0.539 \\
\hline \multicolumn{7}{|l|}{ Instruments Used } \\
\hline Cash and Short Term Inv. Vol. & YES & & & & YES & \\
\hline Book Equity Vol. & & YES & & & YES & \\
\hline Total Asset Vol. & & & YES & & YES & \\
\hline Total Assets & & & & YES & YES & \\
\hline European Dummy & & & & & & YES \\
\hline $\mathrm{N}$ & 25538 & 25538 & 25538 & 25538 & 25538 & 25538 \\
\hline
\end{tabular}

